Institute of $\mathbf{F}_{\text {ood and }} \mathbf{A}_{\text {gricultural }} \mathbf{S}_{\text {ciences }}$

\title{
New, Emerging, and Threatening Plant Diseases and Crop Biosecurity 1
}

Tim Momol, Jim Marois, Bob McGovern, Pam Roberts and Gail Wisler ${ }^{2}$

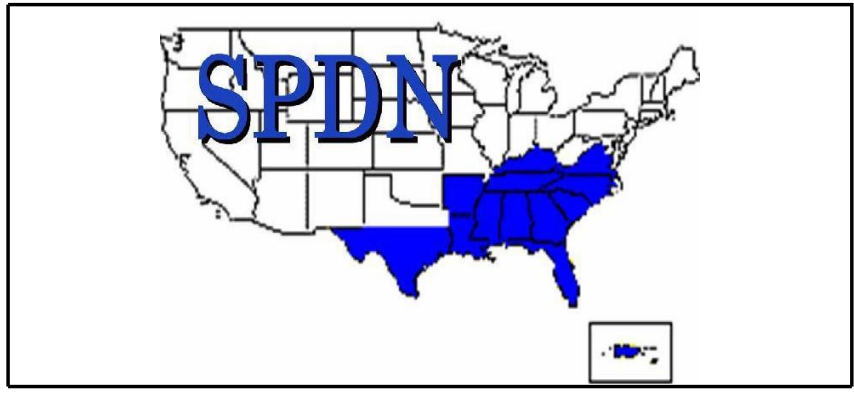

Figure 1. Southern Plant Diagnostic Network (SPDN) "Educate to detect"

\section{SPDN: New Network for Crop Biosecurity}

UF/IFAS recently received a major grant award to help prevent "crop bioterrorism" by protecting crop plants from new introduction of pathogens, insects, nematodes, and weeds.

Five land grant universities (Univeristy of California at Davis, Cornell University, University of Florida, Kansas State University, and Michigan State University), in the United States have been designated as the coordinators for their Plant Diagnostic Regional Centers for the U.S. Plant
Disease Surveillance and Detection Network. A homeland security grant from the U.S. Department of Agriculture (USDA) is providing the initial funding for a new Southern Plant Diagnostic Network (SPDN) ( http://spdn.ifas.ufl.edu ) at the University of Florida (UF) coordinated by IFAS. The University of Florida established this network with 11 other southern states and one U.S. territory (Alabama, Arkansas, Georgia, Kentucky, Louisiana, Mississippi, North Carolina, Puerto Rico, South Carolina, Tennessee, Texas, Virginia -see Figure 1) to improve regional capabilities for rapid and accurate identification and diagnoses to safeguard against newly introduced and re-emerging pests and pathogens, genetically modified pathogens, pesticide-resistant pathogens, and natural changes in endemic organisms.

The mission of SPDN as regional coordinator is to promote the health and security of plants by intercepting and preventing plant diseases and pests that could threaten our agriculture. In response to recent national concerns for bioterrorist activities that can affect our crop and food supply, the Diagnostic

1. This document is Fact Sheet PP195, one of the Plant Pathology Department, Florida Cooperative Extension Service, Institute of Food and Agricultural Sciences, University of Florida. Published April 2003. Please visit the EDIS Web site at http://edis.ifas.ufl.edu.This publication is also a series of the Southern Plant Diagnostic Network (SPDN).

2. Tim Momol, assistant professor, Plant Pathology Department and Jim Marois, professor, Plant Pathology Department, North Florida Research and Education Center, Quincy; Bob McGovern, professor, Plant Pathology Department; Pam D. Roberts, assistant professor, Southwest Florida Research and Education Center (SWREC), Immokalee; Gail Wisler, professor, Plant Pathology Department; Cooperative Extension Service, Institute of Food and Agricultural Sciences, University of Florida, Gainesville, FL 32611.

The Institute of Food and Agricultural Sciences is an equal opportunity/affirmative action employer authorized to provide research, educational information and other services only to individuals and institutions that function without regard to race, color, sex, age, handicap, or national origin. For information on obtaining other extension publications, contact your county Cooperative Extension Service office. Florida Cooperative Extension Service/Institute of Food and Agricultural Sciences/University of Florida/Christine Taylor Waddill, Dean. 
Networks will seek to accomplish their missions by working with partners throughout the U.S. to (i) enhance diagnostic capabilities and establish a secure, regional network for the detection and diagnosis of plant health problems, and better track the health of crops and/or the spread of pests, (ii) extend and support sound public policies, implement rapid and accurate diagnoses, and (iii) provide leadership and training.

New plant diseases caused by fungal, bacterial and viral pathogens have appeared at an alarming rate in Florida in the last two decades. Plant pathologists have described those findings in scientific journals, and the media has shown great interest in this issue. Citrus canker in Florida, for example, has been a highly visible disease problem discussed, sometimes daily, in the popular media. Legitimate concerns on citrus canker raised by citrus growers in Florida received immediate attention by all state and federal agricultural organizations. The eradication efforts of FDACS in collaboration with scientists from UF/IFAS and USDA, have been aimed at limiting and recovering from serious disease and pest (http://www.doacs.state.fl.us/ pi/peac-full.pdf) introductions.

In light of recent national concerns for crop biosecurity, new, emerging and threatening plant diseases have received more attention from all interested parties. Geographically, the state of Florida is uniquely at risk for the introduction of new pathogens and pests of plants and animals, and the climate is highly conducive to maintaining disease-inducing organisms year-round. Due to its location, heavy visitor traffic and climate, Florida has experienced at least 4-5 new plant diseases per year. UF/IFAS Plant Disease Clinics and plant pathologists in Florida actively assist the agricultural industry in Florida and the US by rapid and accurate detection, diagnosis, and development of management recommendations for these new diseases.

\section{Disease Categories}

The American Phytopathological Society (APS) is taking a leadership role in the US to increase awareness of crop biosecurity issues. In an APSnet feature article, Damsteegt (1999) described five pathogen categories. We are suggesting a similar approach:

1. New Disease. Disease described on a new host within last five years in a new geographic area.

2. Emerging Disease. Disease incidence has increased within the last 10-15 years.

3. Re-emerging Disease. Previously known disease in an area, but gaining importance due to pesticide resistance, vector shift, changes in cultivars or culture, or natural changes in endemic pathogens, and other reasons.

4. Threatening Disease. Disease not reported or very limited in distribution in a new geographic area.

5. Chronic/spreading Disease. Known for a longer period in an area but still causing out breaks.

Lists of new and emerging diseases in Florida (Table 1) and elsewhere have been developed. See these Web sites - NCSU site:

http://www.ces.ncsu.edu/depts/ent/clinic/Emerging/ vdis.htm

Damsteegt (1999) APS site: http://www.apsnet.org/online/feature/NewViruses/ Top.html

Madden (2001) APS site http://www.apsnet.org/online/feature/exotic/

\section{Crop Biosecurity}

Literature on crop biosecurity and biological warfare (BW) related to plant pathogens is limited. An APSnet feature article by Schaad et al. (1999) summarized the subject and presented references. Schaad et al. (1999) mentioned the difficulties of determining precise causes for the emergence of new diseases, and added "the remote possibility that some new diseases could have occurred as a result of deliberate introduction."

For further info please visit these web pages: http://www.apsnet.org/online/feature/NewViruses/ Top.html http://www.apsnet.org/online/feature/BioSecurity/ Top.html 
Plant pathologists, personnel in plant disease clinics, county extension offices and private sector are the first line of defense against new diseases. In the state of Florida, the four official plant disease clinics, many plant pathologists at several RECs, and 67 county extension offices, are networked against a potential threat from introduced plant pathogens. UF/IFAS's Web-based Distance Diagnostic and Identification System (DDIS - http://ddis.ifas.ufl.edu ) is playing an important role in the accomplishment of this goal. Improvement in the infrastructure of plant disease clinics, and the DDIS capabilities of county extension offices is essential for defense against new diseases.

Scientists at UF/IFAS, USDA, and FDACS are providing research support for discoveries, rapid detection, and identification of plant pathogens. For a more secure future of Florida's crop and food supply, research in epidemiology, molecular biology, and in all disciplines of plant pathology, need further enhancement. Whether BW related or not, this investment is still needed to maintain the competitiveness of Florida's Agriculture. Specific areas that need further research are the following:

- molecular detection methods, PCR, realtime PCR

- epidemiology and management of new and exotic plant diseases

- molecular fingerprinting techniques

- development of disease resistant genotypes through classical breeding and genetic engineering

- enhanced distance diagnostics, machine vision, and electronic nose

\section{County Extension Faculty (First Detector Educators) and First Detectors - backbone of the SPDN}

If you encounter an unfamiliar disease symptom on any plant, immediately send samples to the closest plant disease clinic or plant pathologist. Take digital images of the symptoms and send them to multiple plant pathology specialists through DDIS. Diagnostic fees may not be charged for samples concerned with crop biosecurity and new diseases in Florida. Prepare newsletter and media articles on the subject of crop biosecurity to increase awareness among your clientele and Florida citizens. For further information, or in an emergency situation, contact one of the plant disease clinics and offices listed below.

Gainesville: Florida Extension Plant Disease Clinic. P.O. Box 110830, U.F., Bldg. 78, Mowry Rd., University of Florida, Gainesville, FL 32611-0830. Note: For overnight mail or package delivery service (UPS, Fedex, etc.) be sure to include the physical street address: "UF, Bldg. 78, Mowry Rd." Phone: (352) 392-1795 or Suncom 622-1795, FAX: (352) 392-3438, E-mail: pdc@mail.ifas.ufl.edu

Quincy: Florida Extension Plant Diagnostic Clinic-Quincy. North Florida REC,155 Research Road, Quincy, FL 32351. Phone: (850)-875-7140, FAX (850) 875-7148, E-mail: tmomol@ufl.edu

Immokalee: Florida Extension Plant Disease Clinic-Immokalee. Southwest Florida REC, 2686 SR 29 North, Immokalee, FL 34142, Phone: (239) 658-3432 or Suncom 975-3400, FAX (941) 658-3469, E-mail: pdr@mail.ifas.ufl.edu

Homestead: Florida Extension Plant Disease Clinic-Homestead. Tropical REC, 18905 S.W. 280th St., Homestead, FL 33031-3314. Phone: (305) 246-6340 or Suncom 478-6340, FAX (305) 246-7003, E-mail: rtmcm@ mail.ifas.ufl.edu

SPDN Director: Dr. Gail Wisler, (352) 392-3631 ext 210

\section{Contacts in the Southern Region and U.S. for University Plant Diagnostic Clinics}

American Phytopathological Society Web site: http://www.apsnet.org/directories/ univ_diagnosticians.asp 
Table 1. List of important new and emerging diseases in Florida. This is a dynamic list and subject to change in time.

\begin{tabular}{|c|c|c|c|}
\hline Disease & Pathogen & Major Hosts & Internet Source \\
\hline $\begin{array}{l}\text { Bacterial Fruit } \\
\text { Blotch }\end{array}$ & $\begin{array}{l}\text { Acidovorax avenae } \\
\text { subsp. citrulli }\end{array}$ & Watermelon & http://doacs.state.fl.us/\%7Epi/enpp/pathology/fruit-blotch.html \\
\hline Citrus Canker & $\begin{array}{l}\text { Xanthomonas } \\
\text { axonopodis pv. citri }\end{array}$ & Citrus spp. & $\begin{array}{l}\text { http://doacs.state.fl.us/\%7Epi/enpp/pathology/cank377.html } \\
\text { http://www.aphis.usda.gov/ppq/ep/citrus/index.html }\end{array}$ \\
\hline Daylily Rust & $\begin{array}{l}\text { Puccinia } \\
\text { hemerocallidis }\end{array}$ & Daylily & http://doacs.state.fl.us/\%7Epi/enpp/pathology/daylily-rust.html \\
\hline $\begin{array}{l}\text { Tomato Yellow } \\
\text { leaf curl } \\
\text { (TYLC) }\end{array}$ & $\begin{array}{l}\text { TYLCV (new strains } \\
\text { or New } \\
\text { Begomoviruses) }\end{array}$ & $\begin{array}{l}\text { Tomato } \\
\text { Ornamentals }\end{array}$ & $\frac{\text { http://edis.ifas.ufl.edu/NFREC1 }}{\text { http://doacs.state.fl.us/\%7Epi/enpp/pathology/updatetyl.htm }}$ \\
\hline $\begin{array}{l}\text { Tomato spotted } \\
\text { wilt (TSW) }\end{array}$ & $\begin{array}{l}\text { TSWV (new strains) } \\
\text { New Tospoviruses }\end{array}$ & $\begin{array}{l}\text { Tomato } \\
\text { Peanut } \\
\text { Tobacco } \\
\text { Potato } \\
\text { Pepper }\end{array}$ & $\begin{array}{l}\text { http://plantpath.ifas.ufl.edu/takextpub/FactSheets/circ0914.pdf } \\
\text { http://thrips.ifas.ufl.edu/ } \\
\text { http://www.oznet.ksu.edu/tospovirus/ }\end{array}$ \\
\hline $\begin{array}{l}\text { Impatiens } \\
\text { necrotic spot } \\
\text { (INS) }\end{array}$ & INSV & Ornamentals & http://www.oznet.ksu.edu/tospovirus/ \\
\hline Bacterial Wilt & $\begin{array}{l}\text { Ralstonia } \\
\text { solanacearum } \\
\text { especially race } 3\end{array}$ & $\begin{array}{l}\text { Tomato } \\
\text { Potato } \\
\text { Tobacco } \\
\text { Geranium } \\
\text { Ornamentals }\end{array}$ & $\begin{array}{l}\text { http://ibws.nexenservices.com/ } \\
\text { http://plantpath.ifas.ufl.edu/takextpub/FactSheets/circ1207.pdf } \\
\text { http://edis.ifas.ufl.edu/PP103 } \\
\text { http://edis.ifas.ufl.edu/CV162 } \\
\end{array}$ \\
\hline Karnal Bunt & Tilletia indica & Wheat & http://www.aphis.usda.gov/ppq/emergencyprograms/karnalbunt/ \\
\hline $\begin{array}{l}\text { Bacterial streak } \\
\text { \& bulb rot of } \\
\text { onion, sourskin } \\
\text { of onion, } \\
\text { slippery skin of } \\
\text { onion, Pantoea } \\
\text { blight of onion, } \\
\text { and Erwinia and } \\
\text { Pseudomonas } \\
\text { soft rots of } \\
\text { onion. }\end{array}$ & 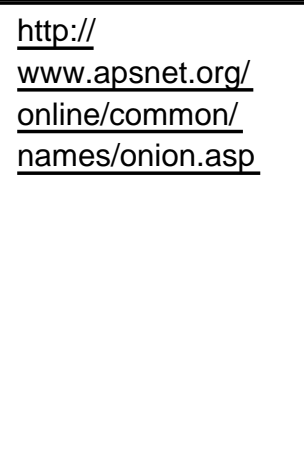 & Onion & http://www.plant.uga.edu/faculty/gitaitis.htm \\
\hline $\begin{array}{l}\text { Citrus } \\
\text { variegation }\end{array}$ & $\begin{array}{l}\text { Citrus variegation } \\
\text { ilarvirus (CVC) }\end{array}$ & Citrus & http://image.fs.uidaho.edu/vide/descr223.htm\#Nomenclature \\
\hline $\begin{array}{l}\text { Pierce's } \\
\text { Disease }\end{array}$ & Xylella fastidiosa & $\begin{array}{l}\text { Grape, } \\
\text { ornamentals, } \\
\text { and more }\end{array}$ & http://www.cnr.berkeley.edu/xylella/ \\
\hline Plum Pox & $\begin{array}{l}\text { Plum pox virus } \\
\text { (PPV) }\end{array}$ & Stone fruits & $\begin{array}{l}\text { http://sharka.cas.psu.edu/ } \\
\text { http://www.aphis.usda.gov/ppq/ep/plumpox/index.html }\end{array}$ \\
\hline $\begin{array}{l}\text { Potato } \\
\text { mop-top }\end{array}$ & $\begin{array}{l}\text { Potato mop-top } \\
\text { virus (PMTV) }\end{array}$ & Potato & http://www.aphis.usda.gov/ppq/ep/emergingpests/moptopvirus.html \\
\hline Soybean Rust & Phakopsora spp. & Soybean & $\begin{array}{l}\text { http://www.aphis.usda.gov/ppq/ep/pestdetection/soybean_rust/ } \\
\text { soybeanrust.html }\end{array}$ \\
\hline
\end{tabular}

